\title{
Validation Study in the Educational Context of the Portuguese Version of the Multidimensional Work Motivation Scale ${ }^{1}$
}

\author{
Lurdes Neves ${ }^{2}$ \\ Universidade do Porto, \\ Porto, Portugal
}

\author{
Joaquim Luís Coimbra \\ Universidade do Porto, \\ Porto, Portugal
}

\begin{abstract}
The self-determination theory proposes a multidimensional concept of motivation and distinguishes how different types of motivation can be promoted or discouraged. For the application of the theory of self-determination to the educational context, this study aimed to adapt and validate the Multidimensional Work Motivation Scale (MWMS) in the educational context. The scale was answered by 419 teachers from 30 schools from the North and Center of Portugal. Factor analysis indicated that the 19-item scale has the same factor structure as that obtained in the original study. In this study, it was possible to identify that the items that constitute the MWMS are good indicators of constructs to be measured in an educational context and the factors are properly individualized. The scale showed five robust dimensions that permit a broad understanding of motivation, similar to the studies of the original scale. The dimension with the best internal consistency is demotivation, while introjected regulation obtained the lowest coefficient.
\end{abstract}

Keywords: self-determination, motivation, questionnaire, teachers

\section{Estudo de Validação em Contexto Educativo da Versão Portuguesa da Escala Multidimensional de Motivação no Trabalho}

\begin{abstract}
Resumo: A teoria da autodeterminação propõe uma conceptualização multidimensional da motivação e distingue como os diferentes tipos de motivação podem ser promovidos ou desencorajados. Para a sua aplicação ao contexto educativo, o presente estudo teve como objetivo a adaptação e validação da Escala Multidimensional de Motivação no Trabalho (MWMS). A escala foi respondidapor 468 professores em 30 agrupamentos de escolas do norte e centro de Portugal. A análise fatorial indicou uma escala de 19 itens com estrutura de fatores semelhante à obtida nos estudos originais. Neste estudo foi possível constatar que os itens que constituem o MWMS são bons indicadores dos construtos que se pretendem medir em contexto educativo e que os fatores se encontram devidamente individualizados. A escala demonstrou cinco dimensões robustas que admitem um entendimento lato da motivação, comuns aos estudos da escala original. A dimensão com melhor consistência interna é a desmotivação e a regulação introjetada é a mais baixa.
\end{abstract}

Palavras-chave: autodeterminação, motivação, questionário, professores

\section{Estudio de Validación en Contexto Educativo de la Versión Portuguesa de la Escala Multidimensional de Motivación en el Trabajo}

\begin{abstract}
Resumen: La teoría de la autodeterminación propone una conceptualización multidimensional de la motivación y distingue como los diferentes tipos de motivación pueden ser promovidos o desalentados. Para su aplicación en el contexto educativo, la presente investigación tuvo como objetivo la adaptación e validación de la Escala Multidimensional de Motivación en el Trabajo (MWMS). La escala fue aplicada a 468 profesores en 30 Escuelas del Norte y Centro de Portugal. El análisis factorial indicó una escala de 19 ítems con una estructura de factores semejante a la obtenida en los estudios originales. En esta investigación fue posible constatar que los ítems que constituyen el MWMS son buenos indicadores de los constructos que se pretenden medir en contexto educativo y que los factores se encuentran debidamente individualizados. La escala demostró cinco dimensiones robustas que admiten una comprensión amplia de la motivación, comunes a los estudios de la escala original. La dimensión con mejor consistencia interna es la desmotivación, mientras que la regulación introyectada es la más baja.
\end{abstract}

Palabras clave: autodeterminación, motivación, cuestionario, profesores

${ }^{1}$ Paper deriving from the doctoral dissertation by the first author, under the advice of the second author and co-advice of the second author, under the Doctoral Program in Psychology at Universidade do Porto, Portugal.

${ }^{2}$ Correspondence address: Universidade do Porto. Departamento de Psicologia. Rua Alfredo Allen, Porto, Portugal. 4200-135. E-mail: pdpsi11006@fpce.up.pt.
At times of globalization, the contemporary organizational behavior theories need a cross-cultural application (Steers, Monday, \& Shapiro, 2004). Hence, the most recent motivation theories focus on this same cross-cultural validation (Steers, Monday, \& Shapiro, 2004) and on the application to various 
domains of life. The self-determination theory - SDT (Deci \& Ryan, 1985) stands out, presenting a multidimensional concept of motivation, permitting the evaluation of the quality of motivation. Therefore, following the adaptation and validation of the Multidimensional Work Motivation Scale (MWMS) to the Portuguese population (Gagné et al., 2015), the main objective of this research is the psychometric adaptation and validation of the scale specifically to the educational context, and the exploration of the psychometric properties of the Motivation Scale.

\section{The Self-Determination Theory}

The SDT that in the present study is applies to work in an educational context proposes a multidimensional view on motivation and distinguishes how different types of motivation can be promoted or discouraged, in a continuum of behaviors, ranging from the absence of motivation to externally regulated motivational behaviors that can be progressively internalized, leading to intrinsic motivation. For the SDT, three main categories of motivation are distinguished: demotivation, intrinsic motivation and extrinsic motivation.

First, the concept of demotivation (Deci \& Ryan, 2011a, 2011b, 2012; Ryan \& Deci, 2011) is defined as the absence of motivation for an activity. Second, intrinsic motivation is defined as the ability to do an autonomous activity, that is, because it is interesting and enjoyable. Third, extrinsic motivation refers to the commitment to activities for instrumental reasons, such as receiving rewards, approving, avoiding punishment and/or disapproval, increasing selfesteem, or reaching a personally valued goal. Taking into account this diversity of instrumental reasons, SDT also specifies different subtypes of extrinsic motivation, which vary in the way they are internalized.

According to the theory, the process of internalization refers to the action oriented by a value of a particular goal or activity that was initially regulated by external factors such as rewards or punishments, so that it becomes internally regulated (Deci \& Ryan, 2011a, 2011b, 2012; Ryan \& Deci, 2011). A first form of extrinsic motivation that is not fully internalized is the external regulation, which refers to the performance of an activity to obtain rewards or punishments administered by others. On the other hand, introjected regulation refers to the regulation of behavior through the internal pressure of forces such as ego involvement, shame and guilt. This form of internalization is experienced as internal control (Deci \& Ryan, 2011b). Finally, the identified regulation refers to the performance of an activity, because it identifies with its value or meaning assumed, so that this form of internalization is volatile.

The identification differs from the intrinsic motivation in the activities in which it is not realized by internal satisfaction, but by the instrumental value it represents. In contrast, internally controlled motivation and demotivation have been the explanation for most desirable results at the behavioral, attitudinal and affective levels (Deci \& Ryan, 2011a, 2011b, 2012; Ryan \& Deci, 2011). Depending on the research question, however, it is sometimes preferable to use the first order of factors - demotivation, external, introjected, identified and intrinsic motivation - since these motivational subtypes have different attitude results in certain domains, such as motivation for the preservation of the environment (Pelletier, Tuson, Green-Demers, Noels, \& Beaton, 1998) and politics (Koestner, Losier, Vallerand, \& Carducci, 1996). Therefore, it becomes necessary to develop a scale for each of the different forms of motivation.

\section{The Multidimensional Work Motivation Scale - MWMS}

There are scales that are based on SDT in various domains of life, such as the academic (Vallerand et al., 1992) or sports domain (Pelletier, Rocchi, Vallerand, Deci, \& Ryan, 2013). Regarding the field of work, Blais, Brière, Lachance, Riddle and Vallerand (1993) published the first scale of motivation based on SDT, in French, despite problems with the internal validity and with the scale of extrinsic regulation (Cronbach's alpha coefficients of only 0.50 ) which encouraged Tremblay, Blanchard, Villeneuve, Taylor and Pelletier (2009) as well as Gagné et al. (2015) to develop the scale (in French and English). These scales, however, had some problems, such as following the tradition of asking people why they did an activity, which in the workplace could be problematic and led to the development and validation of the MWMS. This is a scale that considers the motivation for work in its field of analysis (Vallerand, 1997) and, for this reason, it was selected to develop its adaptation and validation to the educational context, differing from other measures of motivation for work-oriented tasks (Fernet, Senécal, Guay, Marsh, \& Dowson, 2008). MWMS attempts to develop and distinguish itself from previous scales in four different ways.

First, most motivational measures based on SDT follow the tradition of questioning the person through statements that reflect different types of behavioral regulation (Deci \& Ryan, 2011b). Examples include statements such as: "Why do you do this work?" (Blais et al., 1993), which are appropriate to the field of sport but can be problematic in the field of work. As employment is defined as a service contract between employee and employer and in exchange for money, the MWMS items reflect this contingency between the workers and the payment they receive more strongly and clearly, and that appears in items such as "Why do you or would you strive in your current job/employment" in order to be able to identify the (current and latent) reasons for the actual work performance.

A second improvement of the MWMS compared to the previous scales refers to the inclusion of the "external regulation" and "introjected regulation" scales, which were created to balance the reasons for the approach and avoidance of work and to avoid confusion between the concepts of "external regulation" and "introjected regulation" (Assor, Vansteenkiste, \& Kaplan, 2009). In earlier scales, the items of external regulation were more oriented toward 
pursuing rewards and prizes, while the items of "introjected regulation" were more oriented toward avoidance of guilt and shame. Additionally, the MWMS included items that focused on material retributions such as money, as well as social constraints such as being proud that they are important in the work context (Stajkovic \& Luthans, 1997).

Thirdly, in the MWMS, it should have caution for the writing of the items to differ from related concepts such as the satisfaction of the needs of autonomy, competence, intrinsic and extrinsic values and a harmonious or obsessive passion for work (Grouzet et al., 2005; Noels, Pelletier, Clément \& Vallerand (2003); Van den Broeck, Vansteenkiste, De Witte, Soenens, \& Lens, 2010; Vansteenkiste et al., 2007). For example, the items referring to "demotivation" refer to low satisfaction of the need for competence, for example: "I ask myself, I am not able to perform the most important tasks of this work" (Tremblay et al., 2009), and identification items with the intrinsic value of the affiliation "because, in my opinion, it is one of the best ways to meet people" (Pelletier et al., 2013). Finally, to achieve cross-cultural equivalence, the items were written so as to be interpretable in the various cultures in which the scale was validated.

Next, we will focus on the main objective of this investigation, which consists in the adaptation and psychometric validation of MWMS to the teacher population, and in the exploration of its psychometric properties.

\section{Method}

\section{Participants}

The sample is made up of 468 teachers from 30 different School groups, offering school levels ranging from preschool to high school. Of these participants, 374 (79.9\%) are female and the rest male.

Regarding the age, 62 (13.2\%) participants are up to 40 years of age, $214(45.7 \%)$ are between 40 and 50 years old and $192(41.0 \%)$ are between 50 and 60 years old. In terms of years of experience, the majority, 204 (43.6\%) have more than 25 years of professional experience. Regarding academic qualifications, most participants, 411 (87.8\%), are licensed.

\section{Instrument}

The Multidimensional Work Motivation Scale (MWMS) consists of 19 items and is intended to evaluate the motivation for work. In the adaptation to the educational context, the word work is used, meaning the employment situations in the context of Schools or School groups in which the employer is the State.

The MWMS encompasses five dimensions: (1) Demotivation, which consists in the absence of motivation for an activity; (2) Extrinsic regulation, which refers to commitment to activities for instrumental reasons, such as receiving rewards, approval, avoiding punishment and/or disapproval, increasing self-esteem, or reaching a personally valued goal. External regulation refers to the performance of an activity to obtain rewards or punishments administered by others. This dimension includes two types of regulation: the social and material extrinsic regulation; (3) Identified regulation, which refers to the performance of an activity because it identifies with its value or meaning, so that this form of internalization is volatile; (4) Introjected regulation refers to the regulation of behavior through the internal pressure of forces such as ego-involvement, shame and guilt. This form of internalization is experienced as internal control (Deci \& Ryan, 2011b); (5) Intrinsic Motivation, which consists in the ability to do an autonomous activity, that is, because it is interesting and enjoyable.

The items in each dimension are evaluated on a sevenpoint Likert scale, where $1=$ nothing, $2=$ very little, $3=\mathrm{a}$ little, $4=$ moderately, $5=$ strongly, $6=$ very strongly and $7=$ completely. In Table 1, the Cronbach's alpha coefficients of the MWMS are displayed as obtained in other languages and in this study.

Table 1

Cronbach's alpha coefficients of MWMS in other languages and in this study

\begin{tabular}{lcccccc}
\hline & English & French & Norwegian & German & Chinese & Present Study \\
\hline Demotivation & 0.79 & 0.81 & 0.95 & 0.78 & 0.87 & 0.93 \\
Extrinsic Regulation & 0.76 & 0.74 & 0.84 & 0.80 & 0.77 & 0.90 \\
Introjected Regulation & 0.70 & 0.74 & 0.79 & 0.55 & 0.88 & 0.77 \\
Identified Regulation & 0.75 & 0.78 & 0.88 & 0.95 & 0.89 & 0.89 \\
Intrinsic Motivation & 0.90 & 0.88 & 0.94 & & & 0.89 \\
\hline
\end{tabular}

\section{Procedure}

Data collection. The MWMW was adapted to the educational context (Gagné et al., 2015) in Portugal. In order to adapt the items of the scale to the population of our study, the Portuguese version of the instrument was sent to five judges (three teachers and two psychologists who were knowledgeable on the educational context) to develop the semantic adequacy, certifying the global adequacy of all items to the Portuguese context, so that the adaptation process of the instrument to the semantic adequacy level was considered concluded in accordance with Brislin (1986). 
A pre-test was also carried out with 25 teachers to analyze whether the instrument was clearly written and permitted the correct completion.

After the adaptation process, face-to-face contact was made with the Directors of 30 School groups and Secondary Schools, who received explanations on the objectives of the present study and were asked to participate in this study. Additionally, the Director placed a link to complete the questionnaire in the online portal of each school and group. The teachers also received by email the link to the questionnaire and they were asked, in addition to participating in the study, to disseminate it among their fellow teachers under the same conditions. Data were collected between September and December 2015 and 468 valid questionnaires were collected.

Data analysis. The collected data were inserted in a base to analyze: (1) the underlying factor structure and the homogeneity of the items within each of the scales, using exploratory factorial analysis (Principal Axis Factoring); (2) to verify reliability through the internal consistency indicator (Cronbach's alpha); (3) and to verify the psychometric quality of the evaluation model through confirmatory factor analysis (maximum likelihood method). The Statistical Package for the Social Sciences ${ }^{\circledR}$ (SPSS, version 22.0) and Analysis of Moment Structures $^{\circledR}$ (SPSS AMOS, version 19.0) were used to perform the statistical analyses and build the databases.

\section{Ethical Considerations}

The principle of participation in this study is based on a free and informed decision about the nature, implications and risks of this participation. The participants received information for the purpose of free and informed consent. This information was provided before they had access to the questionnaire and also at the beginning of the questionnaire itself.

\section{Results}

\section{Exploratory Factor Analysis (EFA)}

The analysis of the correlation matrix showed significant correlations $(p<0.001$ and $p<0.05)$ with coefficients between $r=-0.27$ and $r=0.85$. No overly or perfectly correlated items were observed. Thus, there are no problems at the level of multicollinearity and singularity, respectively (Field, 2013).

Prior to EFA, criteria were established for the retention of items in each of the following scales: (1) saturation $\geq$ 0.40 of each item in the hypothetical factor and in only one factor; (2) consistency between the factorial solution and the items in each factor; and (3) each factor is represented by at least 3 items (Field, 2013; Osborne \& Fitzpatrick, 2012). These criteria were applied and did not lead to the removal of any items.

We verified the factorability of the data matrix, as the KMO value is higher than $0.60(\mathrm{KMO}=0.85)$ and the Bartlett sphericity test is significant $(p<.001)$. The analysis of commonalities revealed values between 0.42 and 0.97 , presenting an average of 0.72 , thus reflecting that $72 \%$ of the variance associated with the items is common or shared.

EFA was used, by means of the Principal Axis Factoring method with orthogonal rotation (varimax procedure). An analysis of the inflection points in the scree plot and a verification of the eigenvalues were carried out, which led to the extraction of five factors. The scree plot indicated that no more than five factors should be extracted and this solution met the Kaiser normalization criterion (eigenvalue $\geq 1$ ). The five-factor solution extracted explains $71.90 \%$ of the total variance. The order of factors is as follows: extrinsic regulation, demotivation, intrinsic motivation, identified regulation and introjected regulation.

The analysis of Table 2 shows that four items present factor loadings $<0.70$, but these are considered reasonable $(>0.45)$. The remaining items have a factor loading $>0.70$, which is considered excellent (Field, 2013).

Regardless of the order of factors, in the remaining tables, the information will be presented following the order of dimensions related to the continuum referred in the SDT, that is, starting with the demotivation and ending with the intrinsic motivation. Observing Table 3, it can be verified that the intrinsic motivation correlates negatively with the demotivation $(r=-0.098)$ and positively with the introjected $(r=0.177)$ and identified regulation $(r=0.634)$.

Table 2

Factorial structure and commonalities of MWMS

\begin{tabular}{|c|c|c|c|c|c|c|}
\hline & \multicolumn{5}{|c|}{ Factors } & \multirow{2}{*}{$\mathrm{h}^{2}$} \\
\hline & 1 & 2 & 3 & 4 & 5 & \\
\hline I do not struggle because I actually feel that my work is a waste of time. & & 0.836 & & & & 0.775 \\
\hline I do little because I think this work is not worth the effort. & & 0.953 & & & & 0.973 \\
\hline I do not know why I'm at this work, since it's a pointless job. & & 0.836 & & & & 0.753 \\
\hline $\begin{array}{l}\text { To get approval from others (for example, my superiors, my colleagues, } \\
\text { my family, clients ...). }\end{array}$ & 0.820 & & & & & 0.815 \\
\hline
\end{tabular}


continuation...

\begin{tabular}{|c|c|c|c|c|c|c|}
\hline & \multicolumn{5}{|c|}{ Factors } & \multirow{2}{*}{$\mathrm{h}^{2}$} \\
\hline & 1 & 2 & 3 & 4 & 5 & \\
\hline $\begin{array}{l}\text { Because other people will respect me more (for example, my superiors, } \\
\text { my colleagues, my family, parents, students ...). }\end{array}$ & 0.771 & & & & & 0.778 \\
\hline $\begin{array}{l}\text { To avoid being criticized by other people (for example, my superiors, my } \\
\text { colleagues, my family, parents, students ...). }\end{array}$ & 0.721 & & & & & 0.747 \\
\hline $\begin{array}{l}\text { Because only if I work hard enough in my job I will get financial rewards } \\
\text { (for example, leadership ...). }\end{array}$ & 0.730 & & & & & 0.647 \\
\hline $\begin{array}{l}\text { Because only if I try hard enough in my job, they can offer me more job } \\
\text { stability (for example, leadership ...). }\end{array}$ & 0.892 & & & & & 0.931 \\
\hline Because I risk losing my job if I do not try hard enough. & 0.680 & & & & & 0.568 \\
\hline Because I need to prove to myself that I can. & & & & & 0.490 & 0.422 \\
\hline Because it makes me feel proud of myself. & & & & & 0.477 & 0.502 \\
\hline Because otherwise I'll feel ashamed of myself. & & & & & 0.759 & 0.621 \\
\hline Because otherwise I feel bad about myself. & & & & & 0.766 & 0.649 \\
\hline Because I personally consider it important to strive in this work. & & & & 0.715 & & 0.707 \\
\hline Because striving in this work is in line with my personal values. & & & & 0.806 & & 0.817 \\
\hline Because striving in this work has a personal meaning for me. & & & & 0.712 & & 0.682 \\
\hline Because doing my job is fun. & & & 0.678 & & & 0.586 \\
\hline Because what I do in my job is stimulating. & & & 0.926 & & & 0.919 \\
\hline Because the work I do is interesting. & & & 0.807 & & & 0.769 \\
\hline Variance percentage & 23.74 & 13.52 & 12.84 & 11.79 & 10.02 & \\
\hline
\end{tabular}

Table 3

Pearson's correlations among the dimensions

\begin{tabular}{lcccc}
\hline & 1 & 2 & 3 & 4 \\
\hline 1. Demotivation & & & & \\
2. Extrinsic Regulation & $0.455^{* *}$ & & & \\
3. Introjected Regulation & $0.118^{*}$ & $0.381^{* *}$ & & \\
4. Identified Regulation & $-0.161^{* *}$ & -0.065 & $0.402^{* * *}$ & $0.634^{* * *}$ \\
5. Intrinsic Motivation & $-0.098^{*}$ & -0.084 & $0.177^{* * *}$ & \\
\hline
\end{tabular}

${ }^{*} p<.05 ;{ }^{* *} p<.01$

\section{Reliability}

Internal consistency was calculated using Cronbach's alpha coefficient. Analyzing Table 4, it can be verified that the reliability of the MWMS varies between acceptable and high (Marôco, 2011). The dimension with the best internal consistency is demotivation, while introjected regulation has the lowest.

Table 4

Cronbach's alpha coefficients

\begin{tabular}{lccccc}
\hline & $n$ & Mean & S.D. & $\alpha$ & $95 \%$ Confidence Interval \\
\hline Demotivation & 468 & 1.79 & 1.43 & 0.93 & $0.92 ; 0.94$ \\
Extrinsic Regulation & 468 & 2.37 & 1.30 & 0.90 & $0.88 ; 0.91$ \\
Introjected Regulation & 468 & 4.75 & 1.42 & 0.77 & $0.74,0.81$ \\
Identified Regulation & 468 & 6.14 & 0.96 & 0.89 & $0.87 ; 0.90$ \\
Intrinsic Motivation & 468 & 5.26 & 1.15 & 0.89 & $0.87 ; 0.91$ \\
\hline
\end{tabular}




\section{Confirmatory Factor Analysis}

After EFA, a confirmatory factorial analysis was performed to test the model provided by the authors of the original version (Gagné et al., 2015). This model consists of six factors, plus a second order that encompasses social and material extrinsic regulation.

As no adjustment measure provides a conclusive answer to the adjustment of a model, in this study, a range of adjustment indices was used to test the MWMS structure. In order to verify the adjustment of the model, were used the recommendations of several authors (Brown, 2015, Byrne, 2013, Hair, Hult, Ringle, \& Sarstedt, 2013, Marcoulides \& Schumacker, 2013).

Absolute indices do not use an alternative model as a basis for comparison, they derive from the adjustment obtained through covariation matrices and $\mathrm{ML}$ minimization function. The values of $\chi^{2}<3$ and $p>0.05$, SRMR $<0.07$ and RMR close to 0 are considered good. GFI and AGFI values $\geq 0.95$ are considered very good. In this sense, it can be verified through Table 5 that, at the level of absolute indices, the model shows a good to very good adjustment.

Regarding the relative indices, these compare the model tested, an independent model and a saturated model. In the independent model, it is specified that all measured variables are not correlated. The coefficients of NFI, CFI and TLI $\geq 0.95$ are considered very good, and the value of RFI is closer to 1 (Brown et al., 2013, Marcoulides \& Schumacker, 2013). Therefore, as shown in Table 5, at the level of relative indices, the model tested presents a very good adjustment.

The indices of population discrepancy compare the adjustment of the obtained model, the means, the variances of the sample and those that would be obtained from the population. The RMSEA is a function of discrepancy between an estimated matrix and the population matrix, while at the same time accounting for the complexity of the model. PCLOSE is a significance test of RMSEA to verify that the estimated matrix and population matrix are the same. In this sense, RMSEA $\leq 0.05$ (very good) and PCLOSE $>0.05$ (Brown, 2015; Byrne, 2013; Hair et al., 2013; Marcoulides $\&$ Schumacker, 2013) are sought. Hence, it can be affirmed that the adjustment of the model tested is very good. In addition, it can be affirmed that the population matrix and the estimated matrix are the same, and that the mean error in the model is minimal (Table 5).
Table 5

Adjustment measures of structural model: Maximum likelihood

\begin{tabular}{lc}
\hline \multicolumn{1}{c}{ Adjustment statistics } & Model \\
\hline Absolute Indices & $1.349(.131)$ \\
$\chi^{2} /$ df (p-value) & 0.021 \\
$\begin{array}{l}\text { Standardized Root Mean Square Residual } \\
\text { (SRMR) }\end{array}$ & 0.035 \\
Root Mean Square Residual (RMR) & 0.987 \\
Goodness-of-fit Index (GFI) & 0.972 \\
\hline Adjusted Goodness of Fit Index (AGFI) & \\
\hline Relative Indices & 0.989 \\
Normal Fit Index (NFI) & 0.997 \\
Comparative Fit Index (CFI) & 0.982 \\
Relative Fit Index (RFI) & 0.995 \\
Tucker-Lewis Index (TLI) & \\
Population Discrepancy Indices & 0.027 \\
Root Mean Square Error of Approximation \\
$\begin{array}{l}\text { RMSEA) } \\
\text { RMSEA 90\% confidence interval (LO - HI) } \\
\text { PCLOSE }\end{array}$ \\
\hline
\end{tabular}

\section{Discussion}

This research focused on the adaptation and validation of MWMS, an instrument based on the multidimensional concept of motivation inserted in the self-determination theory. This scale had been previously tested in nine different countries and in seven different languages by their authors (Gagné et al., 2015), and showed acceptable behavior.

In this study in an educational context, it could be verified that the items that make up the MWMS are good indicators of the constructs under analysis and that the factors are adequately individualized, similar to what happens in other studies of the scale in 9 countries. The scale demonstrated five robust dimensions that support a broad understanding of motivation. These factors were also observed in studies of the original scale (Gagné et al., 2015).

Concerning the reliability of the instrument, it could be verified that the internal consistency varies between acceptable and high and that only one dimension, of introjected regulation, presents acceptable levels, while the remainder presents high levels of internal consistency. The values found in this study resemble those of the other versions of the scale construction study (Gagné et al., 2015), except for the German version.

With regard to the factor structure of the MWMS, the model indicated by the authors of the original version (Gagné et al., 2015) could be confirmed. The scale showed a structure that includes seven distinct factors, with one second-order factor, which encompasses the social and material extrinsic regulation. In general, the scale adapted and validated to the educational context presented good adjustment indices, similar to the study of the original version (Gagné et al., 2015). Compared with the original version, we also 
observed in this study how intrinsic motivation correlates negatively with extrinsic regulation and amotivation. In sum, the MWMS in the Portuguese version is considered equivalent to the existing versions in other languages and proves to be a robust and reliable instrument to measure, in a multidimensional way, the motivation according to the theory of self-determination.

At the level of practical implications, the application of this measuring instrument in the educational context would provide relevant information on the motivational state of the teachers. This information would be relevant for the implementation of measures and practices that are intrinsic to motivation, or something close such as introjected regulation. That in turn could contribute to an improvement of both the teaching and mental health of teachers.

As limitations and similar to other MWMS applications in other languages, no integrated regulation subscale is included, which is a form of extrinsic motivation that is more internalized than the identified regulation. Previously published scales containing an integration of the subscale show that the identified regulation subscale cannot be statistically separated from intrinsic motivation (Mallett, Kawabata, Newcombe, Otero-Forero, \& Jackson, 2007; Tremblay et al., 2009; Vallerand et al., 1992).

Additionally, the items that measure the motivation integrated in other scales are questionable in terms of their face value, for example, in items that measure the passion for an activity, for example: "because it has become a fundamental part of who I am" (Tremblay et al., 2009). The enthousiasm for work measures explicitly and simultaneously the integration of people's social identity into the activity and their motivation for it (Vallerand et al., 2003), and thus differs from "mere" motivation.

Finally, the MWMS applied to the educational context offers the opportunity to examine, in educational contexts, the distinction between antecedents and consequences of social or material external regulation. We may consider that, with teachers and similar to the results presented in previous research (Ryan \& Deci, 2011), tangible rewards have weak effects on motivation and pride in the accomplishment of the tasks inherent in teaching, while acknowledgement and social rewards can have a more positive impact.

\section{References}

Assor, A., Vansteenkiste, M., \& Kaplan, A. (2009). Identified versus introjected approach and introjected avoidance motivations in school and in sports: The limited benefits of self-worth strivings. Journal of Educational Psychology, 101(2), 482-497. doi:10.1037/a0014236

Blais, M. R., Brière, N. M., Lachance, L., Riddle, A. S., \& Vallerand, R. J. (1993). L'inventaire des motivations au travail de Blais [Blais's work motivation inventory]. Revue Québécoise de Psychologie, 14(3), 185-215. Retrieved from http://www.lrcs.uqam.ca/papers/58.pdf
Brislin, R. W. (1986). The wording and translation of research instruments. In W. J. Lonner \& J. W. Berry (Eds.), Field methods in cross-cultural research (pp. 137164). Thousand Oaks, CA: Sage.

Brown, T. A. (2015). Confirmatory factor analysis for applied research. New York, NY: Guilford.

Byrne, B. M. (2013). Structural equation modeling with AMOS: Basic concepts, applications, and programming (2nd ed.). New York, NY: Routledge.

Deci, E. L., \& Ryan, R. M. (1985). Intrinsic motivation and self-determination in human behavior. New York, NY: Plenum.

Deci, E. L., \& Ryan, R. M. (2011a). Levels of analysis, regnant causes of behavior and well-being: The role of psychological needs. Psychological Inquiry, 22(1), 17-22.doi:10.1080/1047840X.2011.545978

Deci, E. L., \& Ryan, R. M. (2011b). Self-determination theory. In P. A. M. Van Lange, A. W. Kruglanski, \&E. T. Higgins (Eds.), Handbook of theories of social psychology (Vol.1, pp. 416-433). Thousand Oaks, CA: Sage.

Deci, E. L., \& Ryan, R. M. (2012). Motivation, personality, and development within embedded social contexts: An overview of self-determination theory. In R. M. Ryan (Ed.), The Oxford handbook of human motivation (pp. 85-107). New York, NY: Oxford University Press.

Fernet, C., Senécal, C., Guay, F., Marsh, H., \& Dowson, M. (2008). The Work Tasks Motivation Scale for Teachers (WTMST). Journal of Career Assessment, 16(2), 256279. doi:10.1177/1069072707305764

Field, A. (2013). Discovering statistics using IBM SPSS statistics. Thousand Oaks, CA: Sage.

Gagné, M., Forest, J., Vansteenkiste, M., Crevier-Braud, L., Van den Broeck, A., Aspeli, A. K., ...Westbye, C. (2015). The Multidimensional Work Motivation Scale: Validation evidence in seven languages and nine countries. European Journal of Work and Organizational Psychology, 24(2), 178-196. doi:10.1080/1359432X.2013.877892

Grouzet, F. M., Kasser, T., Ahuvia, A., Dols, J. M. F., Kim, Y., Lau, S., ... Sheldon, K. M. (2005). The structure of goal contents across 15 cultures. Journal of Personality and Social Psychology, 89(5), 800-816. doi:10.1037/0022-3514.89.5.800

Hair, J. F., Jr., Hult, G. T. M., Ringle, C. M., \& Sarstedt, M. (2013). A primer on Partial Least Squares Structural Equation Modeling (PLS-SEM). Thousand Oaks, CA: Sage.

Koestner, R., Losier, G. F., Vallerand, R. J., \& Carducci, D. (1996). Identified and introjected forms of political internalization: Extending self-determination theory. Journal of Personality and Social Psychology, 70(5), 1025-1036. doi:10.1037//0022-3514.70.5.1025 
Mallett, C., Kawabata, M., Newcombe, P., Otero-Forero, A., \& Jackson, S. (2007). Sport motivation scale-6 (SMS-6): A revised six-factor sport motivation scale. Psychology of Sport and Exercise, 8(5), 600-614. doi:10.1016/j. psychsport.2006.12.005

Marcoulides, G. A., \& Schumacker, R. E. (2013). Advanced structural equation modeling: Issues and techniques. New York, NY: Psychology Press.

Marôco, J. (2011). Análise estatística com o SPSS Statistics (5a ed.). Pero Pinheiro, Portugal: Report Number.

Noels, K. A., Pelletier, L. G., Clément, R. and Vallerand, R. J. (2003), Why Are You Learning a Second Language? Motivational Orientations and SelfDetermination Theory. Language Learning, 53: 33-64. doi:10.1111/1467-9922.53223

Osborne, J. W., \& Fitzpatrick, D. C. (2012). Replication analysis in exploratory factor analysis: What it is and why it makes your analysis better. Practical Assessment, Research \& Evaluation, 17(15), 1-8.Retrieved from http://pareonline.net/getvn.asp? $\mathrm{v}=17 \& \mathrm{n}=15$

Pelletier, L. G., Rocchi, M. A., Vallerand, R. J., Deci, E. L., \& Ryan, R. M. (2013). Validation of the revised sport motivation scale (SMS-II). Psychology of Sport and Exercise, 14(3), 329-341. doi:10.1016/j. psychsport.2012.12.002

Pelletier, L. G., Tuson, K. M., Green-Demers, I., Noels, K., \& Beaton, A. M. (1998). Why are you doing things for the environment? The Motivation Toward the Environment Scale (MTES). Journal of Applied Social Psychology, 28(5), 437-468. doi:10.1111/j.1559-1816.1998.tb01714.x

Rufini, S. E., Bzuneck, J. A., \& Oliveira, K. L. (2012). A qualidade da motivação em estudantes do ensino fundamental. Paidéia (Ribeirão Preto), 22(51), 53-62. doi:10.1590/S0103-863X2012000100007

Ryan, R. M., \& Deci, E. L. (2011). A self-determination theory perspective on social, institutional, cultural, and economic supports for autonomy and their importance for well-being. In V. I. Chirkov, R. Ryan, \& K. M. Sheldon (Eds.), Human autonomy in cross-cultural context: Perspectives on the psychology of agency, freedom, and well-being (pp. 45-64). Dordrecht, Netherlands: Springer.

Stajkovic, A. D., \& Luthans, F. (1997). A meta-analysis of the effects of organizational behavior modification on task performance, 1975-1995. Academy of Management Journal, 40(5), 1122-1149.doi:10.2307/256929

Steers, R. M., Monday, R. T., \& Shapiro, D. L. (2004). Introduction to special topic forum: The future of work motivation theory. The Academy of Management Review, 29(3), 379-387.doi:10.2307/20159049

Tremblay, M. A., Blanchard, C. M., Taylor, S., Pelletier, L. G., \& Villeneuve, M. (2009). Work extrinsic and intrinsic motivation scale: Its value for organizational psychology research. Canadian Journal of Behavioural Science, 41(4), 213-226. doi:10.1037/a0015167
Vallerand, R. J., Pelletier, L. G., Blais, M. R., Brière, N. M., Sénécal, C., \& Vallières, E. F. (1992). The academic motivation scale: A measure of intrinsic, extrinsic, and amotivation in education. Educational and Psychological Measurement, 52(4), 1003-1017. doi: $10.1177 / 0013164492052004025$

Van den Broeck, A., Vansteenkiste, M., De Witte, H., Soenens, B., \&Lens, W. (2010). Capturing autonomy, competence, and relatednessat work: Construction and initial validation of the work-related basic need satisfaction scale. Journal of Occupational and Organizational Psychology, 83(4), 981-1002. doi:10.1348/096317909X481382

Vallerand, R.J. (1997) Toward a Hierarchical Model of Intrinsic and Extrinsic Motivation. Advances in Experimental Social Psychology, 29, 271-360. http://dx.doi.org/10.1016/S0065-2601(08)60019-2

Lurdes Neves is an Associated Professor of Faculdade de Psicologia e de Ciências da Educação from Universidade do Porto.

Joaquim Coimbra is an Auxiliary Invited Professor of Faculdade de Engenharia from Universidade do Porto.

Received: Mar. 06, 2016

1st Revision: Jun. 28, 2016

Approved: Aug. 11, 2016

How to cite this article:

Neves, L. \& Coimbra, J. (2018). Validation study in the educational context of the portuguese version of the multidimensional work motivation scale. Paidéia (Ribeirão Preto), 28, e2803. doi: http://dx.doi.org/10.1590/1982-4327e2803 